\title{
Implication of Boko Haram Terrorism on Northern Nigeria
}

\author{
Dr. Chukwurah, Daniel C. \\ Department of Public Administration, Nnamdi Azikiwe University, Awka \\ Eme, Okechukwu \\ Ogbeje, Eunice Nmire \\ Department of Public Administration and Local Government Studies, University of Nigeria, Nsukka \\ Email: okechukwunncnt@gmail.com
}

\section{Doi:10.5901/mjss.2015.v6n3p371}

\section{Abstract}

Terrorism has been a global menace which affects economic, political and social status of the country experiencing it. The political dimension of terrorism and insecurity have been examined in this study which moribund political regime of President Goodluck Jonathan in Nigeria. Many lives and properties have been destroyed in Northern Nigeria by the Boko Haram deadly attacks. It is evident from this study that Boko Haram terrorist insurgency invigorated as a result of pronouncement of Goodluck Jonathan as president of Federal Republic of Nigeria. Since the inception of this political regime, Boko Haram has been disrupting and destabilizing government activities mainly in Northern Nigeria. The political implication of terrorism has been deadly in Nigerian democratic governance. The study found that North-Eastern Nigeria witnessed a monumental influx of Boko Haram deadly attacks (115), followed by North-West with (13) attacks while North-Central experienced (12) attacks since last four years, consequently culminated into epileptic socio-political activities in these geo-political zones; many lives have been lost while the Nigerian political environment continue to produce social insecurity and enduring political diaphragm. The challenges of terrorism and insecurity have been traumatizing President Goodluck Jonathan's administration in Nigeria while many political gladiators hide under the siege of Boko Haram insurgency in terrorizing existing political regime in Nigeria which makes it difficult to actualize governmental policies and programmes in Nigeria. Boko Haram terrorism is an ethnic political tool aimed at causing political chaos by political elites in Nigeria; therefore this study makes a prognosis for reawakening of militancy in Niger-Delta if President Jonathan is denied second term presidential political contestation in Nigeria. Regardless of political affiliations, all the political stakeholders should rally round the Jonathan's administration to proffer solution to the current security conundrum in Nigeria. The pull-down political syndrome should be shunned for the sake of general well-being of the citizenry which serves as a bedrock of statecraft.

Keywords: Terrorism, Political Violence, Economic Consequences, Population Displacement, Relative Deprivation and Boko Haram.

\section{Introduction}

Terrorism which has become a global phenomenon is a deliberate and systematic use of violence to destroy, kill, maim and intimidate the innocent in order to achieve a goal or draw national/international attention or demands which ordinarily may be impossible or difficult to achieve under normal political negotiation or on the battle field against a government army. Terrorism whether internationalized or localized is always politically motivated. Though it may also show other auxiliary motives include religion, economic or social reasons. These motives constitute the ideology of a case for which terrorism seeks solution or sympathy of all terrorist groups that have ravaged Nigeria. The Boko Haram is undoubtedly the most blood thirsty and destructive both in terms of its demonic brutality, mindless savagery and increasingly in scope of operation (Obioma, 2009). From Harmless group of 12 has in recent times increased to more than 10,000 violent members (Akpan et al, 2012). According to Innocent and Ibietan (2012) "Boko Haram is an indigenous salafist group which turned itself into a salafist Jihadist in 2009. The group was founded by Mohammed Yusuf in 2002 in the city of Maiduguri with the aim of establishing a Sharia government in Borno State under former Governor Ali Modu Sheriff. He established a religious complex that included a Mosque and a school where many poor families from across Nigeria and from neighbouring countries enrolled their children". From the beginning, the group made its manifest known: Rejection of western education, institutions, and agencies that go with it, including government institutions. It prefer to have a sharia law applied all over the country, but if that is difficult to grant, they would rather have a separate Islamic state carved out 
of Nigeria, where they can practice their religion unhindered. If this is not granted Nigeria will be made ungovernable.

Government saw these demands as treasonable, unreasonable and unacceptable and in an attempt to purge the group of its excesses their leader Mohammed Yusuf died in 2009 from that year onwards under the assumption of a new leader named Abubakar Shekau, Boko Haram reinvented violence and began what can best be described as the bombardment of Northern Nigeria with such frequency and intensity that are quite unprecedented in history of violence in Nigeria. Those who escape death by day, sleep with one eye open by night. The Boko Haram has created widespread tension across Northern Nigeria and between various ethnic communities, interrupted commercial activities, frightens investors and generated concerns among Nigerians northern neighbours. This unprecedented state of terrorism by the Boko Haram sect in Nigeria has ruined the tranquility of the northern atmosphere and high rate of insecurity pervading northern region in particular and the nation/Nigeria in general is alarming and is a cause for serious concern to well meaning Nigerians. It is for this reason that this paper is set and aimed at speculating the possible negative effect of Boko Haram terrorist activities on the economy of Northern Nigeria and by extension Nigeria.

\section{Statement of the Problem}

From the activities of Boko Haram ,Nigeria has now been certified as a full fledged terrorist state, a classification that brings untold odium on us all. Several violent attacks by the Boko Haram have affected economic activities in Maiduguri, Kano, Yobe and other cities in the north-east many resident has fled their homes while others who could relocate hardly go about their normal business. Shooting and bombing linked to Boko is forcing people to hunker down in their homes or abandon/the northern region. Business activities are fizzling out, most residents are living on their savings, and there is ban on motobikes which is the main means of transportation, growing unemployment among traders. Recession has set in. To this end this work will be bounded by these research questions:

(1) What was the state of northern economy before the activities of the Boko Haram?

(2) What is the present state of the northern economy since, the commencement of the Boko Haram activities?

(3) What are the possible/future negative effect of Boko Haram terrorist activities on the economy of northern Nigeria and by extension Nigeria.

(4) What steps and policy measures can be taken to alleviate and combat the negative effect of the Boko Haram terrorist activities on the northern economy and by extension Nigeria and subsequently stop their activities.

\section{Objectives of the Study}

The general goal of this study is to speculate the possible negative effect on Boko Haram activities on the northern economy and by extension Nigeria, while the particular aims and objectives of this study are:

(1) To find out the state of northern economy before the activities of the Boko Haram.

(2) To examine the state of northern and Nigerian economy since the start/operation of the Boko Haram sect in Nigeria.

(3) To speculate the possible negative effect on Boko Haram terrorist activities of the economy of the northern Nigeria and by extension Nigeria.

(4) To make recommendation with a view to alleviating and combating the already existing negative effect of Boko Haram activities on northern economy and by extension Nigeria and subsequently stopping their activities.

\section{Methodology}

The area of study is to speculate on the possible negative effect of Boko Haram Terrorist activities on the economy of northern Nigeria and by extension Nigeria. Data for this research were generated using the secondary data - Books, Journals, Newspaper articles, Magazines, Seminar and Conference papers and internet materials. Data was analyzed using content analysis method. The population of the study is Nigerian while the target or sample population is the northern region.

\section{Contextualising Terrorism}

Terrorism is a complex issue that has been studied and debated for several decades. In fact, there are dozens of competing definitions of the term, not only among scholars but among policymakers and government agencies as well. But one thing holds constant terrorist attacks do not occur in a vacuum, but are instead a product of complex interactions 
between individuals, organizations, and environments. Further, there are many different kinds of terrorism, defined primarily by ideological orientations like ethno-nationalism, left-wing, religious, and so forth. And just like there are many different kinds of terrorism, there are many different kinds of contexts in which terrorism occurs (Forest, 2012). Terrorism is increasingly understood as a political act meant to inflict dramatic and deadly injury on civilians and to create an atmosphere of acute fear and despair (generally for a political or ideological, whether secular or religious, purpose), but the term is notoriously difficult to define. The use of violence to create fear, often through the targeting of third parties and with the elements of surprise and the undermining of very personal security, is a tool used by a variety of historical and contemporary actors (Large, 2005). Terrorism is a term used to describe violence or other harmful acts. Walter Laqueur in 1999 counted over 100 definitions of terrorism and concludes that the only characteristics generally agreed upon are that terrorism involves, violence and the threat of violence (Laqueur, 2003 cited in Eke, 2013). The etymology of terrorism is derived from Latin words "terrere" which means "frighten". Terrorism is a special crime associated with violent, victimization, threatening, frightening, and disruption of socio-political atmosphere in a particular society. It is an act of bombing, killing, kidnapping, maiming and destruction thereby creating socio-political tension, extremely fear, and destabilizing existing government or political opposition. It implies deadly attack on government agency and functionary, international organization, military and civilian in order to gain international recognition.

Terrorism is the use of violence and intimidation to achieve political ends. Terrorists want to change the way governments and politicians behave. They do not do this by voting or by trying to convince people of their arguments. They do it by frightening people into behaving the way the terrorists want (BBC, Monday July 11 2005). Kydd \& Walter (2006) cited in Atere \& Alao (2012) define terrorism as actions focusing on harming some people in order to create fear in others by targeting civilians and facilities or system on which civilians rely (Eke, 2013). Terrorism may be viewed as a method of violence in which civilians are targeted with the objective of forcing a perceived enemy into submission by creating fear, demoralization and political friction in the population under attack (Schmid \& Jongman, 2005). In most cases, their actions do lead to the loss of innocent lives. Just as non-state actors and rogues states are known to commit terrorism at home and abroad, democratic countries also do the same in order to achieve political, religious, or other objectives (The Punch Newspaper, May 23, 2012). Terrorism, in the most widely accepted contemporary usage of the term, is fundamentally and inherently political. It is also ineluctably about power: the pursuit of power, the acquisition of power, and the use of power to achieve political change. Terrorism is thus violence or, equally important, the threat of violence used and directed in pursuit of, or in service of, a political aim (Hoffman, 1998). As a form of unconventional warfare, terrorism is sometimes used when attempting to force socio-political change by convincing a government or population to agree to demands to avoid future harm or fear of harm, destabilization of existing government, motivating a discontented population to join a mutiny, escalating a conflict in the hope of upsetting the status quo, expressing an injustice, or drawing attention to a cause. The United States Federal Bureau of Investigation (FBI) defined terrorism as Involve violent acts or acts dangerous to human life that violate federal or state law; Appear to be intended to intimidate or coerce a civilian population; to influence the policy of a government by intimidation or coercion; or to affect the conduct of a government by mass destruction, assassination, or kidnapping.

The United States Department of Defense defines terrorism as "the calculated use of unlawful violence or threat of unlawful violence to inculcate fear; intended to coerce or to intimidate Governments or Societies in the pursuit of goals that are generally political, religious, or ideological". Within this definition, there are three key elements- violence, fear, and intimidation-and each element produces terror in its victims

Political terrorism is the deliberate use or threats of violence against noncombatants, calculated to instill fear in an audience beyond the immediate victims. He says that because perpetrators of terrorism often strike symbolic targets in a horrific manner, the psychological impact of an attack can exceed the physical damage. He concluded that terrorism is a mixture of drama and dread. Despite the fact that terrorism could not be said to be a senseless violence, rather it is a premeditated political cum social strategy that threaten people with a coming danger that seem ubiquitous, unavoidable and sometimes unpreventable (Kegley, 2011 cited in Raji, 2013).

The U.S. Department of State defines "Terrorism" as "premeditated politically-motivated violence perpetrated against non-combatant targets by sub-national groups or clandestine agents, usually intended to influence an audience (Zumve, Ingyoroko and Akuva, 2013). Terrorism is a failure of political process that begins with in-equalities, corruption and injustice in a given political system, and moves from a frustrated attempt at reform that breed fear and anger, to political confrontation and conspicuously erupted into violence. This can be exploited to rationalize the use of any form of violence against any target. It seems that solutions to terrorism could be found at any stage of the evolving, or deteriorating political and social processes (Dempsey 2006 cited in Isyaku, 2013). For this paper, political aspect of terrorism shall be considered. In terms of political terrorism, Shultz \& Sloan (1980) cited in Oviasogie (2013) defined it as the threat and/or use of extra normal form of political violence, in varying degrees, with the objective of achieving certain 
political goals or objectives. This is to influence the behaviour and attitude of certain groups. It has basically political motives. Cline and Alexander (1987) ) cited in Oviasogie (2013) defined terrorism as a deliberate employment of violence or the use of violence by sovereign states as well as some national groups, assisted by sovereign states in order to attain strategic and political objectives through the violation of law.

\section{Eight Signs of Terrorism}

The New Hampshire Department of Safety suggests 8 signs of terrorism which include the following:

> Surveillance - Someone recording or monitoring activities. This may include the use of cameras, note taking, drawing diagrams, annotating on maps, or using binoculars or other vision-enhancing devices.

> Elicitation - People or organizations attempting to gain information about military operations, capabilities, or people. Elicitation attempts may be made by mail, e-mail, telephone, or in person. This could also include eavesdropping or friendly conversation.

$>$ Tests of Security - Any attempts to measure reaction times to security breaches, attempts to penetrate physical security barriers, or monitor procedures in order to assess strengths and weaknesses.

$>$ Funding - Suspicious transactions involving large cash payments, deposits, or withdrawals are common signs of terrorist funding. Collections for donations, the solicitation for money and criminal activity are also warning signs.

$>$ Supplies - Purchasing or stealing explosives, weapons, ammunition, etc. This also includes acquiring military uniforms, decals, flight manuals, passes or badges (or the equipment to manufacture such items) and any other controlled items.

> Impersonation - People who don't seem to belong in the workplace, neighborhood, business establishment, or anywhere else. This includes suspicious border crossings, the impersonation of law enforcement, military personnel, or company employees is also a sign.

$>$ Rehearsal - Putting people in position and moving them around according to their plan without actually committing the terrorist act. An element of this activity could also include mapping out routes and determining the timing of traffic lights and flow.

$>$ Deployment - People and supplies getting into position to commit the act. This is the person's last chance to alert authorities before the terrorist act occurs.

\section{Theoretical Framework}

The theories guiding this work are: Systems theory and Relative deprivation theory. The system analysis of the political system popularized by David Easton is adopted as a theoretical approach underpinning the study. The system theory is an analogy that shows a collection of interrelated parts which forms some whole. The idea is that if all the parts are working effectively the overall objectives can be achieved. A system can be open or closed. Nigeria is an open system. A key feature of open systems is their interdependence on the environment which may be relatively stable or relative uncertain at a particular point in time. This feature is of considerable importance to political and economic system which needs to adapt to the changing environment if they are to flourish. Nigeria needs the Northern economy to achieve her economic objectives. The focus of the approach is on the analysis of factors and forces that engender stability and instability in the political system strengthens its relevance to explaining the deep linkage between the dysfunctionality in governance and the challenges of poverty, inequality and insecurity in Nigeria. The political system within the Eastonian framework is an input and out-put mechanism which deals with political decisions and activities and performs integrative and adaptive functions relevant to the transformation of the society (Johari, 2011). Moreover, the mix of the environment, citizens' demand and support (inputs), and the policy output from the system are core factors that affect the structures and processes involve in the authoritative allocation of values and are thus fundamental to the stability and survival of the political system (Johari, 2011).

The centrality of citizens' demand and support (inputs) and policy output to the failure of democratic governance in Nigeria and the attending social tensions and security threats it provokes is the major concern of the study. The inputs in the political system according to Easton consist of citizens' demands on the polity and the support they extend to the system. Supposedly, inputs in this context refer to those demand made by the Boko Haram. Demands made upon the political system by the political elites and leadership is with-in inputs. Meanwhile, supports entail the structures that enable the political system to manage demands put on it, while outputs relate to those demands that are converted into authoritative policies and decisions. Importantly, obtaining a balance among these critical variables of the political system 
is germane to its capacity to overcome inevitable challenges pose by the various forces from within, as well as the maintenance of stability and survival of the polity. Conversely, the inability of the political system to address critical demands from the Boko Haram, or respond positively to important feedback from its policy outputs have the capacity to undermine support for it. Moreover, intra-elite conflicts regarding policy articulation or allocation of scarce resources, preference for elites demands and inability of the structures and institutions of the system to manage citizens' demands equitably can engender popular distrust, instability and stresses of the political system (Johari, 2011).

The political leadership is characterized by blatant personalization of power, predatory, parochial, prebendal and patrimonial dispositions (Jega, 2007). These ills no doubt undermine popular participation and the critical role of the masses in setting the agenda of governance. The dominant role of the political elites in setting, shaping and articulating governmental policies at the expense of the general interests of the populace erodes public support in democratic governance and policies as the masses perceive and equate democratic governance with representing the interest of the ruling elites (Olaniyi, 2001). The fact that in most cases the outcome of the elitist imposed policies consist of widespread unemployment, corruption and poverty tend to worsen the peoples' sense of alienation and frustration in the political system, which often translate into disobedience of the state an the resort to violence as a means to challenge the legitimacy of the state. This explains in part the Boko Haram militancy in the North. It is within this context that the worsening social tensions, economic inequality, poverty and increased spate of insecurity in the country since Jonathan's administration.

Relative deprivation is the experience of being deprived of something to which one believes to be entitled. It refers to the discontent people feel when they compare their positions to others and realize that they have less of what they believe themselves to be entitled than those around them (Davis, 2011). Some scholars of social movements explain their rise by citing grievances of people who feel deprived of what they perceive as 'values' to which they are entitled. Similarly, individuals engage in deviant behaviour when their means do not match their goals. Relative deprivation theory holds that instead of an absolute standard of deprivation, a gap between expected and achieved welfare leads men to violence (Claire, 2011). Claire went further to provide a psychological approach to explain how collective discontent is manifested in violence. According to him, the primary source of human capacity for violence appears to be the frustration aggression mechanism. The anger induced by frustration is a motivating force that disposes men to aggression, irrespective of its instrumentalities. In the words of Omer Taspinar (2012), Relative deprivation is the gap between high expectations and missing opportunities. To him, social, cultural, political and economic awareness grows at the heart of relative deprivation and this in turn fuels expectations. When these expectations are not forthcoming, the deprived could resort to violence to seek redress. All the views expressed boils down to the major thrust of the relative deprivation theory which holds that 'when people are deprived of things which they deem valuable in the society whether money, justice, status or privilege join social movements with the aim of redressing their grievances'.

When applied to the Boko Haram insurgence in the north, we submit that the loss of a spiritual leader in the person of Mohammed Yusuf deprived the sect members of a role model, source of inspiration and a spiritual guide whom the sect boldly needed at the formative stage to nurture and grow the new faith. The arrest and subsequent death of some sect members in the hands of security agents was to the group, a deprivation of the right to life of their loved ones and brotherly love and affection which those deceased provided while they were still alive. Furthermore, the refusal of the Federal government to fully abolish western education and allow for an Islamic model was to the sect, a deprivation of the right to home grown model of education which will conform to the custom and tradition of the Islamic faith. The refusal of the Federal government led by Dr. Goodluck Jonathan to sign and thus make way for the immediate establishment of the Islamic state for the entire north was to them, a deprivation of the right to self-governance/ rule as Jonathan's presidency was seen by them as an imposition of an unbeliever to rule over the Muslim territory. Also, the refusal of Christian minority to leave the north was to the sect, a deprivation of the right to a territorial integrity devoid of sinful infidels who according to the sect pollute and profane a holy territory of 'Allah' the only God.

\section{Method of Data Collection}

For this study, information was collected using secondary sources of data collection. The secondary source of data used for this research work comprises of those collected from published textbooks, papers, Journal such as social sciences, business, management and government Journals, online materials, articles as well as seminar papers were used to get relevant information. 


\section{Findings}

From our research and study, these are our findings:

(1) That the northern economy before Boko Haram terrorist activities was and used to be a bubbling and thriving economy but now is grounded to a halt; consider these examples.

(a) The transport sector - road and air - thrives very much. Road transport fetch a transporter of 13 seater bus the range of $\mathrm{N} 40-45,000$ a week on two trips while the Nigeria air line industry was estimated to be making about N3 billion very day. But now analysts say that half of this amount is lost daily. Passenger traffic to north has reduced drastically dealing a big blow to this sector (Madlion, 2012, Innocent and Ibietan, 2012). It takes much more effort to get passengers to fill just a 13 seater bus going to the North.

(b) The tourism sector which ranked first in the country Nigerian and generates approximately N80 billion annually has been held stand still. The famous Argungu fishing festival, Yankari Games Reserves, the Mambila Plateau, the tomb of Othman Dan-Fodio, all of which attracts tourists from within and outside the country have been paralyzed alongside the various economic activities within value chain (NTDC, 2012).

(c) The infrastructural sub-sector of the northern economy has been devastated. This is because a good number of foreign and local contractors across the various northern states engaged in the construction of roads, bridges, housing estate development, the dams, National Integrated Power projects and rail way track rehabilitation have either abandoned sites or relocated to other states. This represents real setback to the economy of the region and pushes unemployment higher as thousands of youth who would have been engaged by them now sit idle.

(d) The commercial sector which was once booming now witnesses a dwindling fortune. The commercial subsector which covers the small and medium scale enterprises, local markets, road side shops and stores within the affected states have been closed down because most of these businesses are owned by southerners most of whom are Igbos. Chinedu (2012) noted that $73.3 \%$ of business has partially closed operations in northern Nigeria because of this insecurity. This represents huge capital flight from northern economy in both human and financial terms. The most affected states in this regard are Borno, Yobe, Kano and Sokoto. Kano for example serves as a commercial nerve centre not only for the north but also neighbouring Countries like Chad, Niger, Cameroon and Western Sudan for past 500 year before evolution of Nigeria. Obeche (2012) noted that some \$15 billion do flow through Kano's market each year and two million traders used to arrive daily from Nigeria and neighbouring countries selling goods from factories in the south or imported from Asia. It has the oldest and biggest multi billion naira textile market known In the sub-Saharan African - The Kanti Kwari market. But now because of the Boko Haram activities the market is stifled. Kano economy has crashed, Business is fizzling, income generated has dwindled. People find it difficult to make ends meet. Most times people come to market without selling anything. (Babajide, 2012) (IRIN news 2012, Eme and Ibietan 2012).

(e) In the core service sector, schools, hospitals, hotels, parks and recreational outfits are going down. Foreign students are relocating down to the south; many doctors have transferred to other peaceful states, hotels and parks now records low turn-out of visitors. All these portend losses to northern economy.

Before now there are more than enough Human resources for business and production including professionals in different service sectors. But now some of them have lost their lives resulting in mass exodus from the north to the south for safety. As of now, there is no direct evidence that those who migrated because of insecurity have returned to the northern states they fled. The Health, banking and insurance, and Education sector have crumbled. Even vacancy announcement with attractive salary and benefits are not responded to (Madlion, 2012).

(f) The Agricultural sector is not left out. Most northerners are known to be engaged in this sector. Agricultural output is dwindling greatly. Farmers in Kaduna, Plateau, and Sokoto no longer go to farm for fear of what will happen to them. Presently, the northern economy is crippled.

It will take 20 years to recover from the current predicament the north has found itself (Chiendu 2012).

In summary the negative effect of the of the Boko Haram terrorist activities to the northern economy now is that it has stifled normal process of trade and investment to the northern economy, the effect has been intense so much so that presently it has created a suppressive and crippled economy. It will take at least 20 years to recover from the current predicament in which the northern region has found itself (Chiedu 2012)(2) That if the Boko Haram terrorist activities continue the possible negative effect will be a systemic distortion of the existing economic pattern and structure in the northern region, devastated economy as a result of loss of lives, properties, mass exodus of non-indigenes as well as 
indigenes, death/decline in investments and tourism, transportation, agriculture and commercial activities, dearth of professionals and artisans. The northern economy will be gone and The northern region will gradually disappear.

(3) On the Nigerian economy - historically each region in Nigeria complements the other. What the north lacks the South provides if this Boko Haram activities persists it will alter this economic symphony. If the suppression, crippling and systematic distortion done to northern economy is transmitted to other regions of Nigeria, the negative effect it will have on the Nigerian economy are: Bad macro economic environment and instability suppressive economy which will complicate Nigeria business climate and make it investor unfriendly- both foreign and local, widening of the gap between the north and other regions greatly, cost of living and value of properties will be very high at the back of pressure. Reduction in the flow of foreign Direct investment, break down of industrial production, hindering greater productivity and meeting the nations production target, wastages, exacerbate the already bleak years for investors in the Nigerian stock exchange, decline in economic growth and development - already the Nigeria GDP is regressing -, high incidence of poverty and unemployment, foreign investors will fold their mats for exodus.

In conclusion, if this Boko Haram terrorist activities continue the northern economy will collapse completely because trade and investment will be stifled, the economy and the economic objectives of Nigeria including the vision 20:2020 will be a mirage and will not be achieved and consequently the Nigerian economy will collapse, the nation will no longer compete favourably in the global marhen this happens, Nigeria will attain the status of a failed state.

\section{Recommendation}

Our study showed that Boko Haram capitalizes on popular frustration with leaders, poor government service delivery, and dismal living conditions of many northerners. Based on these insights we hereby make the following recommendations:

1. The Boko Haram crisis is already having domestic domino effect concerted effort is needed at this stage so as to forestall a spillover effects to the other region. The economic cost of government's inaction would be utterly calamitous. To this end, a fact-finding commission, involving all major stakeholders should be convened to interact with all those who are directly or remotely connected to Boko Haram so that the spate of violence can stop.

2. There is also urgent need to make leadership in the north to show deeper concern for the problem at hand. They must reach out to Boko Haram leadership who live among them and find ways of talking to them to drop their guns and bombs. This is important because the economy in the north and indeed Nigeria is under great threat and the time to act is now.

3. Since poverty and unemployment are among the root cause of Boko Haram insurgence there is an urgent need for a robust social protection scheme with special preference for the north. Food, shelter, health care and employment creation should be the bedrock of this scheme. Women, children and youths should be the target they should be empowered through vocational training. While mosque, churches, and NGOs should be utilized. The North need to know that the president is going extra-ordinary length to fix their problem.

4. Government should redouble its effort at Nation building, take a hard look at the root causes of the current problems in order to find lasting solution to Boko Haram insurgency and other terrorist group.

5. An improved intelligence gathering is needed to curb future violence. What we are witnessing in Nigeria are the consequences of lack of national intelligence security system that fails to recognize that contemporary system demands more reliable and timely intelligence than guns and armoured personnel carriers.

6. Government should as a matter of urgency review its current approach and expand its effort to combat the militant activities and be more responsive to issues of security by genuinely tackling them to minimize their dangerous implications, thus improving the investment climate.

7. The popular claim by the top northerners that disgruntled and unscrupulous extremists from Chad and Niger constitute the majority of the sect members should not be treated with kid gloves. With regards to this; the federal government must strengthen our custom service to tighten our borders and solicit for the co-operation of the government of Niger and Chad to check border movements.

8. There is need for a comprehensive national data base to capture relevant data which would aid in documentation and monitoring of the general populations.

9. Government will have to develop a new social compact with its northern citizens and evolve an economic recovery strategy to complements its security strategy.

10. We reject in its totality the call for amnesty for the Boko Haram Sect as it will send a bad signal to other militia groups like OPC and MOSSOB to the effect that the government of Nigeria understand only the language of 
violence and they will want to toe the same line.

11. We support the current state of emergency declared in the most affected states. However, the defense headquarters must ensure that their operations are in line with internationally recognized best practices to avoid gross violation of human rights.

To this end the researchers are very confident that if these recommendations which are unambiguous, down to earth and far reaching are implemented religiously, in no distant time, Sokoto- the Seat of the Caliphate will regain its spiritual relevance, Kano will become a bedrock of economic activities again, the beautiful savannah of Adamawa will blossom and a dew of peace shall calm the boiling atmosphere of Borno while the economy of the northern region will flourish again, the whole nation will be better for it.

\section{References}

Abiodun .F. (2012), Democracy and National Identities: The Travails of National Security in Nigeria; British Journal of Arts and Social Sciences ISSN: 2046-9578, Vol.9 No.II

Abubakar, A. (2013), Business Day (2012), Boko Haram: What cost for the Northern Economy www.businessdayonline.com>news> latest.

ACLED, (2013), Country Report: Nigeria; available at www.acleddata.com

Adagba .O. Ugwu .S. and Eme, O.I (2012), activities of Bokoharam and insecurity question in Nigeria; Arabian Journal of Business and Management Review (OMAN Chapter) Vol. 1, No.9

Aderenle, A. R. (2012), Boko Haram in Surgery in Nigeria as a Symptom of Poverty and Political Alienation, IOSR Journal of Humanities and Social Science, Vol. 3, No.5.

Agbiboa .D. (2013), The Ongoing Campaign of Terror in Nigeria: Boko Haram versus the State Stability; International Journal of Security \& Development, 2(3):

Akinlade .M. and Ibitoye .M. (2012), Eliminating Terrorism and Sustaining Democracy in Nigeria; Political Science Department College of Education, Ikere-Ekiti, Ekiti State, Nigeria

Akpan .B., Onwuka and Onyeizugbe (2012), Terrorist Activities and Economic Development in Nigeria: An Early Warning Signal; International Journal of Sustainable Development, Vol. 05, No. 04

Akpan et al (2012), Terrorist Activities and Economic Development in Nigeria: An Early Warning Signal, OIDA International Journal of Sustainable Development, Vol. 5, No.4.

Akpomera .E. and Omoyibo .K. (2013), Boko Haram Terrorism in Nigeria: The Paradox and Challenges of Big Brother Foreign Policy; Published by International Journal of Arts and Humanities Vol. 2 (1), Serial 5,

Alao .D. Atere .C. (2012), Bokoharam insurgence in nigeria: the challenges and lessons;Singaporean journal of business economics, and management studies Vol.1, No.4

Alfa .P. and Otaida .E. (2012), Political Violence and the Negation of Democratic Stability in Nigeria: Implication for the Fourth Republic; Journal of Physical Sciences and Innovation, Volume 4 Al Jazeera Report, Tuesday 31 July 2012

Alozieuwa, .S. (2012), Contending Theories on Nigeria's Security Challenge in the Era of Boko Haram Insurgency; The Peace and Conflict Review Volume 7, Issue 1; University of Peace

Anyadike .N. (2013), Bokoharam and National Security Challenges in Nigeria; Causes and Solutions; Journal of Economics and Sustainable Development Vol.4, No.5,

Armnesty to Boko Haram and Implication for Nigeria Economy, Business Day, Nigeria.com/amnesty-boko-Haram-and implication. nigeria.

Ayamkpan, C. (2013), Arewa Youths urge Northern Governors to Grant Amnesty to Boko Haram, Retrieved Thursday, June 6.

Babajide, J. (2012), Boko Haram Affects Northern Economy, African Newspapers of Nigeria plc.

Badejogbin .T. (2013), Boko Haram: An enquiry into the socio-political context of Nigeria's counter-terrorism response; Published by Law Democracy \& Development, Volume 17, University of Cape Town

Bamgbose .J. (2013), The Boko Haram Crisis and Nigeria's External Relations; British Journal of Arts and Social Sciences ISSN: 2046-9578, Vol.11 No.ll

Bamidele .O. (2012), Boko Haram Catastrophic Terrorism -An Albatross to National Peace, Security and Sustainable Development in Nigeria; Journal of Sustainable Development in Africa (Volume 14, No.1 BBC, Monday July 112005

Beetseh .k. \& Echikwonye .R. (2011), The Impact of Terrorism and Global Security on the Development of Nigerian Foreign Policy: A Challenge; Journal of Arts and Contemporary Society, volume 3

Bersley .T. and Persson .T. (2010), The Logic of Political Violence; London School ofCIFAR Economics; Institute for International Economic Studies, Stockholm University.

Boko Hram Attack Cripple Northern Economy www.dailytrust.com/../508 .29-boko haram-cripple-northern-n.

Busch, G.K. (2012), Boko Haram and Nigeria, Nigerian Village Square.

Chinedu, A. (2012), Economic implications of insecurity in Nigeria.

Danladi .S. (2013), 21st century questions: the state of Nigeria democracy in peril? Violence and democracy in Nigeria: "Mapping the Rootage"; European Scientific Journal vol.9, No.14

Dasuki, S. (2013), Nigeria's security challenges: The way forward, Leadership Newspaper Nig.

Eke .C. (2013), Terrorism and the Dilemmas of Combating the Menace in Nigeria; International Journal of Humanities and Social Science Vol. 3 No. 4

El-Rufai .N. (2012), Between Terrorism \& Corruption - Implications for Nigeria; lecture delivered at Ahmadu Bello University, Zaria, Nigeria

Eme .O. \& Anthony .O.(2011), "The Challenges of Insecurity in Nigeria: A Thematic Exposition", Interdisciplinary Journal of Contemporary Research in Business, Vol 3, no 8.

Eme, O.I, and Ibietan, (2012), Arabian Journal of Business and Management Review (OMAN Chapter), Vol. 2, No. 2, September.

Eme, O.I. et al (2012), Activities of Boko Haram and Insecurity Question in Nigeria, AJBMR, Vol. 1, (9) April. 
Fayeye .J. (2010), Ethnic Militia: National Security, Democracy and Development; Department of Sociology, University of Ilorin, Ilorin

Forest .J. (2012), Confronting the Terrorism of Boko Haram in Nigeria; published by Joint Special Operations University, 7701 Tampa Point Boulevard

Frazer .E. \& Hutchings .K. (2008), Political Theory Revisited Political Theory Revisited; Journal in Politics and International Relation, Palgrave Macmillan Publisher

Gottesman .R. and Brown .R. (2008), Violence in America: An Encyclopedia; published by Charles Scribner's Son, An imprint of the Gale Group, New York

Gutowski .J. (1998), Domestic Political Violence: Working Towards an Answer to a Timeless Question; published by Illinois Wesleyan University

GVPT (2007), What is Politics; publisher not indicated

Hoffman .B. (1998), Inside Terrorism; Colombia University Press

Insecurity and Nigerian Economy Business Day Newspaper (2012)

Internet Encyclopedia of Philosophy

Isyaku .A. (2013), Terrorism: A New Challenge to Nigeria's Stability in the $21^{\text {st }}$ Century; International Affairs and Global Strategy; Vol.12,

Joshua .S. (2013), Democracy and Violent Conflicts in Nigeria: Implications for National Development; African Research Review; International Multidisciplinary Journal, Ethiopia Vol. 7 (3), Serial No. 30

Kusimo, O. T. (2012), Precision, Boko Haram Menace, others slow Insurance Industry Growth, National Mirrow.

Large .J. (2005), Democracy and Terrorism: The Impact of the Anti; published by International IDEA

Madlion, S.(2013), Boko Haram: Without Amnesty Nigeria World Import Food -Analyst Warns Posted to the net by Channels Television on April 15, 203. Retrieved on June 1

Maiangwa .B. (2013), Killing in the Name of God? Explaining the Boko Haram Phenomenon in Nigeria United Nations University, Institute for Sustainability and Peace, Tokyo Volume 38, Number 1,

Marshall .M. (2006), "Political Violence and War" Publisher (Not Indicated)

Modia, S. M. and Aliu, M. (2013), Governance and Threats to National Security in Emerging Democracies: A Focus on Nigeria the Nigeria, Fourth Republic, Research on Humanities and Social Sciences, Vol.3, No. 4.

Morten .B. (2012), Nigeria: the challenge of "Boko Haram II"; Published by Open Democracy New Hampshire Department of Safety: What is Terrorism?

News and Articles (2013), The Economic cost Terrorist Attacks in Nigeria, News and Articles Personality Profile Publications.

Nigerian Economy in the First Half of 2012 and Revised Economic Outlook for 2012-2015, Nigeriavillage square.com/dr-geng.k/.../book-haramnigeria.html.

Niworu (2013), "Bokoharam Sect: Terrorists or a Manifestation of the Failed Nigerian State," Journal of Politics and Law; Vol. 6, No. 2; 2013 ISSN 1913-9047 Published by Canadian Center of Science and Education

Nwangwu, N. (2013), Analysis: Understanding Nigeria's Boko Haram radicals, IRIN the Humanitarian News and Analysis of the Untied Nation's Office for Coordination of Humanitarian Affairs.

Nwozor .A. (2013), National Security, Religious Anarchism and the Politics of Amnesty in Nigeria; Covenant Journal of Politics and International Affairs (CUJPIA) Vol. 1, No. 1 (Maiden Edition),

Obeche, O. (2009), Boko Haram: will Jonathan's Carot and stick end the siege the Economy Magazine.

Obioma, J.D. (2009), Boko Haram, Domestic Terrorism and the future of Nigeria, The Economy Magazine.

Ojukwu .C. (2009), The Reign of Terror in Democratic Nigeria: A Review of Socio Political and Psychological Implications; Journal of Humanities, Social Sciences and Creative Arts

Okoronkwo, J. (2012), Boko haram: Beyond the Boom-Boom CBN Report, Business Report.

Olanrewaju, T. (2013), Blame Poverty for Boko Haram - CBN The Sun Newspaper, February 16, 2013.

Omale .J. (2013), "Terrorism and Counter Terrorism in Nigeria: Theoretical Paradigms and Lessons for Public Policy", Canadian Social Science, Vol. 9, No. 3,

Osewa, O. (2013), Consequences of the Boko Haran's Activities on the Nigeria Economy-Politics-Niraland.

Oviasogie .F. (2013), State Failure, Terrorism and Global Security: An Appraisal of the Boko Haram Insurgency in Northern Nigeria; Journal of Sustainable Society Vol. 2, No. 1,

Oxford Advanced Learner's Dictionary, 7th International Student Edition; Published by Oxford University Press. PM News, July 2, 2012

Raji .R. (2013), "Nigeria Anti - Terrorism Law and Global Security," Department of Political Science Yobe State University Damaturu, Nigeria Sahara Reporter, April, 252012

Schimid and Jongman (2005), Political Terrorism; published by Transaction Publisher

The Nigerian Voice, 12 August 2012

The Punch Newspaper, May 23, 2012

Utebor, S. (2013), Jonathan Forgive Boko Haram, www.punch.com>news.

United States Federal Bureau of Investigation (FBI)

Vanguard, June 13, 2011

Vanguard, January 22, 2012

Velitchkova .A. (2012), A Habitual Action Theory of Political Violence available at http://www3.nd.edu/ avelitch/VelitchkovaHabitual ActionTheoryViolencewikipedia.com Woodrow Wilson Centre For Scholars

Why Boko Haram persist - by FG. Daily Sun Newspaper, January 1, 2013. www.business day online.com> Analysis > Editorial www.irinnews.org/.../analysis.understanding -Nigerian-s-boko-haram-radic.

www.spyghana.com/ecoimplication-of-security innigera.

www.thenationonlineng.net/../388.60-boko-haram-is-threat-to-nigeria,2012.

Zumve .S. Ingyoroko .M. and Akuva .I. (2013), Terrorism in contemporary Nigeria: a latent function of official corruption and state neglect; European Scientific Journal edition vol.9, No.8 ISSN: 1857 - 7881 